\title{
Movable Surface Irrigation SystemDesign
}

\author{
Mohamed E. El-Hagarey ${ }^{1}$.A.M.El-Kot ${ }^{1}$.A.A.Abdel-Aziz ${ }^{2}$ and A.M.El-Gindy ${ }^{2}$ \\ I- Soil Conservation Department-Desert Research Center. \\ 2- Agricultural engineering Department - Agriculture faculty-Ain Shams University.
}

(1) Corresponding author, elhagarey@gmail.com

\begin{abstract}
Center pivot modification depends on replacing the sprinkler head (sprayer) by polyethylene hoses ending by nozzles.

Field experiments were conducted at the experimental farm of Faculty of Agriculture, in Shams University, to modify sprinkler pivot to work as a moving surface irrigation system. Two different nozzles shapes were selected (trapezoid and triangle) with two different hoses length $(25$ and $200 \mathrm{~cm})$. Pilot area was divided into two halves, the first was straight furrow, while the second was furrow as well as concentrated with track of pivot wheel, and planted maize.

The main objectives of this study are to modify pivot irrigation system to be more suitable to irrigate trees, and other crops under special conditions, to evaluate the modification system and to reduce the investment costs of the modified system.

Results show that, operating the Movable Surface Irrigation System.(MSIS) at low pressure head (1.5 bar), water amount was decreased by (16.8\%), the uniformity coefficient for triangle form was $91.6 \%$,pulled hoses $(200 \mathrm{~cm})$ were better than the short hoses, on the other hand, water use efficiency (WUE) with Movable Surface Irrigation System. system was $\left(2.5 \mathrm{~kg} / \mathrm{m}^{3}\right)$ while it was $\left(1.84 \mathrm{~kg} / \mathrm{m}^{3}\right)$ with sprinkler pivot system and the Movable Surface Irrigation System. system reduced the hazard of chemigation.

The investment cost of the modified system was reduced as compared with traditional system with little energy required for the Movable Surface Irrigation System. system.

There's no significant difference between the two methods of furrow on grain yield of maize.
\end{abstract}

\section{Introduction}

Egypt is mainly an agricultural country in which irrigation technologies plays an important role in supporting national economy. Irrigation water consumes about $85-88 \%$ of the country's water budget for cultivating approximately 8 million feddans with an annual crop area of about 15 million feddans.

Developed irrigation systems are very important for sustainable agriculture, sprinkler irrigation system is one of the most important modern irrigation systemsespecially in new reclaimed areas, but in special cases this system needs to be modified to be more suitable for this region,Helweg (1989) suggestedmodifications to decrease instantaneous application rates are only suitable for row crops . The traveling trickler system designed for grain crops showedpromise of being more efficient, on the other hand, Wilmes et al. (1993)reported that, center pivot systems can be one of the most efficient and uniform method of applying irrigation water if the system is properly good designed and managed, also Broner (2002)reported that, highpressure to low-pressure conversion, a change from high-pressure to low-pressure systems, if done properly reduces pumping costs. However, low-pressure systems require sprinkler heads (water-emitting devices) that usually have a smaller radius of throw that results in higher instant application rates. Higher application rates for lower pressures is the main trade-off between high- and low-pressure systems. However, there are several other factors to consider if you change from high to low-pressure systems or to LEPA systems.

\section{Hydraulics:}

\section{Material And Methods}

The basic modification of pivot system depended on replacing the sprinkler heads by P.E. hoses which can be operated at lower pressure.

For that, it's crystal clear that piezometric head reduces along pivot main line because of friction losses. According to dynamic equal, we can see the reserve relationship between velocity of water flow and section area of flow exits.

it's important to mention that wanted discharge is assumed, at this research discharge is assumed $(0.5$ 1/s ), while the Piezometeric head was measured. And friction losses were calculated according to Darcy Wesbash equation.

A technique characters of simple pivot at Experimental farm, Faculty of Agric., Ain Shams University, for a single tower center pivot irrigation system $(48 \mathrm{~m})$ radius, $(127 \mathrm{~mm})$ diameter of main line, 
thickness of pipe (3) $\mathrm{mm}$, and $(75 \mathrm{~cm}$ )space between holes, according to handbook of pivot technique characters .

$$
\mathrm{D}=\mathbf{5 3 6 . 3}\left[\mathrm{Q}^{0.5} / \mathrm{h}^{0.25}\right]
$$

\section{Where:}

$\mathbf{D}=$ Inside diameter of outlets $(\mathrm{mm})$

$\mathbf{Q}=$ Discharge of outlets $\left(\mathrm{m}^{3} / \mathrm{s}\right)$

$\mathbf{h}=$ Outlets Pizoemeteric head (m)

From calculations it's clear that change of inside diameter hose is very small $(0.02,0.03,0.04$,and 0.05 $\mathrm{mm}$ ). The calculated diameters have very micro changes which are not available at markets which have limited diameters. Therefore, if using the available diameter, it's a must to design the MSIS outfitting. But to achieve this work, the following two steps must be considered:

1 - reducing the diameter to be suitable for calculated diameters.

2 -obtainingsmall change of calculated diameters.

The experimental calculated begun by selecting five categories of hosesinside diameters $(10.5,11,11.5,12$,and $12.5 \mathrm{~mm})$ from calculated diameters to be carried out .

\section{Outfit design of movable surface irrigation system:}

Outfit which design contrasts inside hoses which also constructed at lateral pipe of pivot at sprinkler places by using barbed.

\section{Basic components of movable surface irrigation system outfit:}

- Polyethylene hose (20mm diameter),

- Hose connection (barbed) $(3 / 4 / 20 \mathrm{~mm}$ diameter).

- Cylinder of wood stick (20mm diameter).

Form and cross-section area of hole outlet:
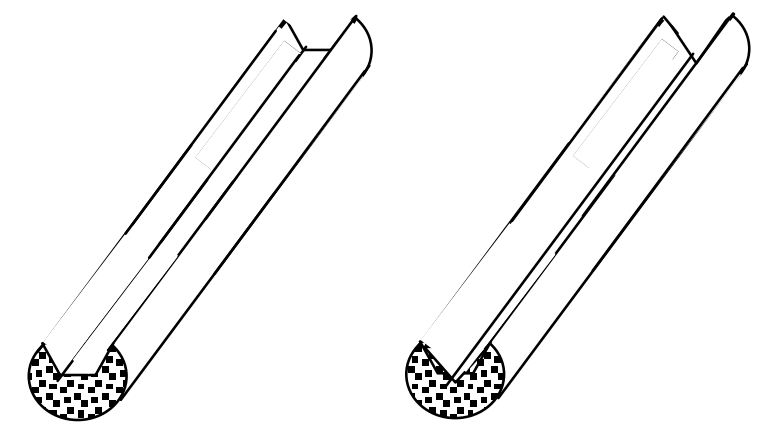

Trapezoid form

Triangle form

Fig. 1: Two forms in cylinder of wood stick.

Two forms of cross-section area of hole outlets were selected the outlets are excavated along the stream ofwood stick cylinder according to designed areas, as shown in Fig.(1)

\section{Trapezoid plus segment of a circle:}

From experimental calculation, this form is produced. It depends on excavated linear tunnel at cylinder of wood to give the wanted section of area

$A_{t}=((a b+c d) / 2) L$

$A_{c}=2 / 3$ L $\times$ ab

Where: $\quad \mathbf{A}_{\mathbf{t}}=$ Area of trapezoid , $\mathrm{mm}^{2}$,

$\mathbf{A}_{\mathbf{c}}=$ Area of segment of circle, $\mathrm{mm}^{2}$,

$\mathbf{a b}=$ String of circle of stick wood section

(the up base of trapezoid) ,mm,

$\mathbf{c d}=$ The down base of trapezoid ,mm,

$\mathbf{L}=$ Altitude of trapezoid ,mm, as shown in Fig.(2): 

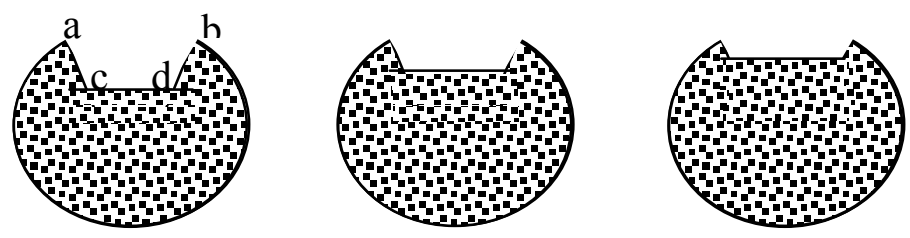

$\mathbf{L}=\mathbf{5 m m}$

$\mathrm{L}=\mathbf{4} \mathbf{~ m m}$

$\mathbf{L}=\mathbf{3} \mathbf{m m}$
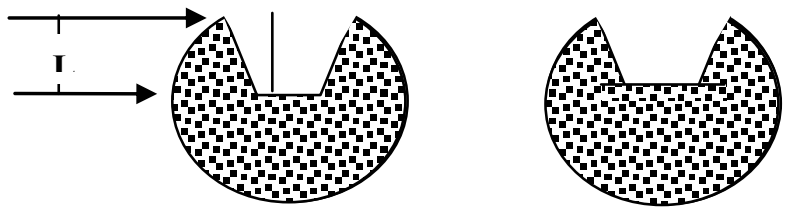

$\mathrm{L}=\mathbf{7} \mathbf{M m}$

$\mathrm{L}=6 \mathbf{m m}$

Fig 2 :Cross section of excavated cylinder of wood at trapezoid form.

Triangle plus segment of a circle:

The experiments appear that suitable change for previous gradually diameters were obtained also by changing of central corner. Where, the changeable area can be obtained from relationship between central corner changing and area changing. The rate of central corner changewas 10 degree, beginning with (100, 110,120,130, and 140 degree ) as shown in Fig.(3)
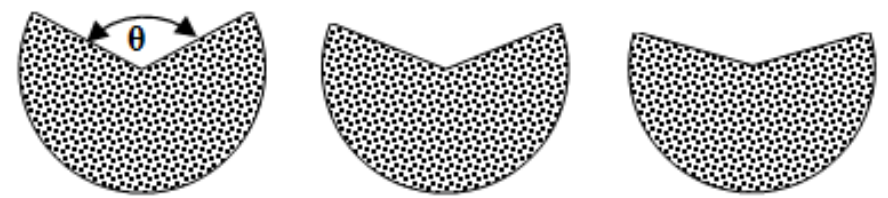

$$
\theta_{3}=120^{\circ}
$$

$$
\theta_{4}=130^{\circ}
$$

$\theta_{5}=140^{\circ}$
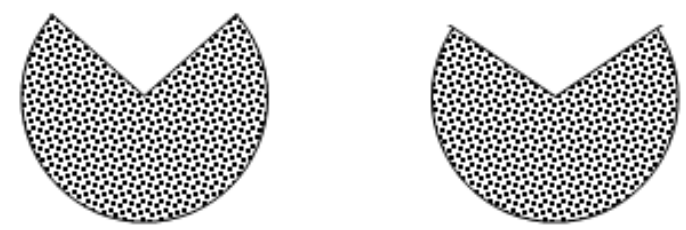

$$
\theta_{1}=100^{\circ}
$$$$
\theta_{2}=110^{\circ}
$$

Fig. 3 :Cross-section of excavated cylinder of wood attraingle form

\section{Hose lengths:}

For two nozzle shapes, there's two length of hoses were fixed, first length is $25 \mathrm{~cm}$ and suspended at 75 $\mathrm{cm}$ from soil surface, second length is $200 \mathrm{~cm}$ and pulled at soil surface as showed at Fig. (4) 


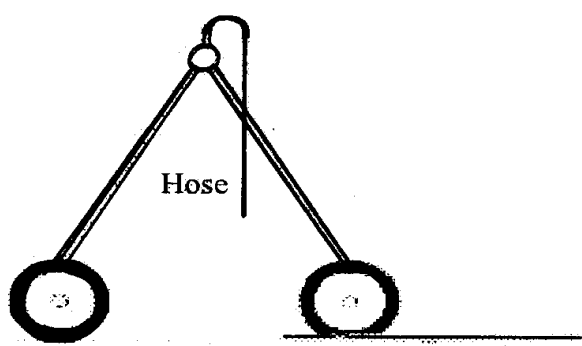

$(25 \mathrm{~cm})$ Length of hose

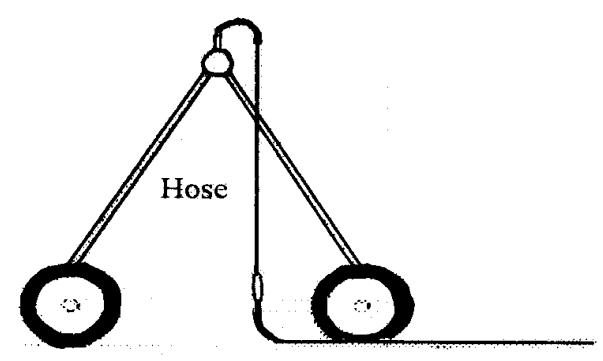

$(200 \mathrm{~cm})$ Length of hose

Fig. 4 : Hoses end (measurement points) and Two lengths of hoses .

\section{Calculatea graauany area:}

$$
\mathbf{A}_{1} / \mathbf{\theta}_{1}=\mathbf{A}_{2} / \boldsymbol{\theta}_{2}
$$

$$
A_{\mathrm{cn}}=\left(\boldsymbol{\theta}_{\mathrm{n}} / \mathbf{3 6 0}\right) \times A_{\mathrm{t}}
$$

Where: $\mathbf{A}_{\mathbf{c n}}=$ Area of triangle plus segment circle $\left(\mathrm{mm}^{2}\right)$,

$\boldsymbol{\theta}_{\mathbf{n}}=$ Central corner, degree,

$\mathbf{A}_{\mathbf{t}}=$ Total area of hose $\left(\mathrm{mm}^{2}\right)$.

\section{Uniformity coefficient evaluation of movable surface irrigation system.pplication:}

\section{Discharge measurements:}

Discharge measurementswere taken with inflow meter for pump, while for nozzleswere taken at next.Samples were taken by selecting 22 from 44 hoses. These samples were taken by received water application at gradual container during periodfrom timeaccording to (Keller and Karmeli, 1975).For reducing experimental error, discharge was measured four times.

Uniformity coefficient was calculated according to (Bralts et al.,1987) .

Where: Uf \% = Uniformity coefficient, $\%$,

$$
\text { Uf \% }=100\left[1-\left(\Sigma Q_{\text {d. }} / Q_{x}\right)\right]----(6)
$$

$\mathbf{Q}_{\mathbf{d}}=$ Absolute deviation of each sample from the mean, 1/s, and

\section{Experiments:}

$\mathbf{Q}_{\mathbf{x}}=$ The mean of outlets discharge, $1 / \mathrm{s}$,

Zea maize was planted under MSIS system at the Experimental Farm of Faculty of Agriculture, Ain Shams University. The last crop is clover. Maize crop (single cross No.10) which is been produced by the Field Crop Dept.ARC, Ministry of Agriculture. The furrow space was $70 \mathrm{~cm}$ while the plant space along furrow was 25 $\mathrm{cm}$

\section{2-4-1- Soil preparation:}

Soil was ridged and planning by two methods [traditional furrow (straight line) and round furrow (with track of pivot wheels)] as showed at Fig.(5).

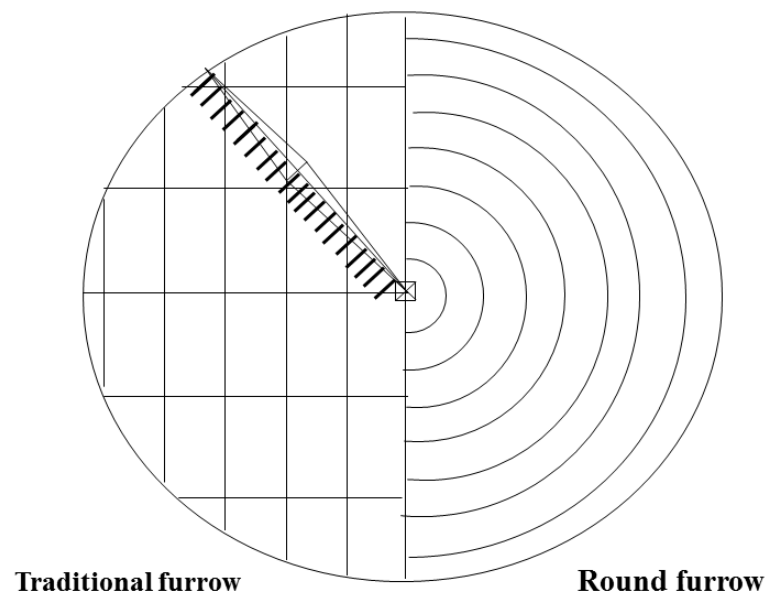

Fig. 5:Traditional furrow and round furrow. 


\section{Irrigation requirements:}

Irrigation water requirements for maize were calculated usingthe data of evapotranspiration which were available at the Central Laboratory for Agricultural Climate (C.L.A.C.), Ministry of Agriculture and land Reclamation. Irrigation requirements were presented in Table (1):

Table (1): Calculated consumptive use ( $\mathrm{mm} /$ day) of maize using pan evaporationmethod.

\begin{tabular}{lccccc}
\hline \multicolumn{1}{c}{ Growth stage } & Period & $\mathbf{E T}_{\mathbf{0}} \mathbf{m m} / \mathbf{d a y}$ & $\mathbf{K}_{\mathbf{c}}$ & $\begin{array}{c}\mathbf{E t}_{\mathbf{c}} \\
\mathbf{m m} / \mathbf{d a y}\end{array}$ & $\mathbf{E T}_{\mathbf{c}} \mathbf{m}^{\mathbf{3}} / \mathbf{f e d} . \mathbf{d a y}$ \\
\hline Initial & $26 / 6-15 / 7$ & 7.2 & 0.40 & 2.88 & 12.096 \\
\hline Develop. & $16 / 7-16 / 8$ & 6.69 & 0.80 & 5.3 & 22.26 \\
\hline Mide season & $17 / 8-7 / 9$ & 6.57 & 1.10 & 7.23 & 30.366 \\
\hline Season end & $8 / 9-23 / 9$ & 4.7 & 0.87 & 4.09 & 17.178 \\
\hline At harvest & $24 / 9-15 / 10$ & 3.97 & 0.57 & 2.26 & 9.492 \\
\hline
\end{tabular}

\section{$\mathbf{E T}_{\mathbf{c}}=$ Water consumptive use}

Irrigation water was applied weekly and calculated crop consumptive use was calculated ( $\mathrm{mm} /$ day) according to(Doorenbos and Pruitt, 1977)

Where:

$$
\mathbf{E t}_{\mathbf{c}}=\mathbf{E t}_{\mathbf{0}} \times \mathbf{K}_{\mathrm{c}}
$$

$\mathbf{E t}_{\mathbf{c}}=$ Crop consumptive use, $\mathrm{mm} /$ day

$\mathbf{E t}_{\mathbf{0}}=$ Reference evapotranspiration, $\mathrm{mm} /$ day

$\mathbf{K}_{\mathbf{c}}=$ Crop coefficient (dimensionless).for maize was used to calculate the Et $t_{\text {crop }}$ values, FAO,(1984)

$-(8)$

$$
\begin{array}{r}
\text { Irrigation time }=\frac{\text { amount of water applied }(\mathrm{m} 3)}{\text { modified pivot discharge }(\mathrm{m} 3 / \mathrm{h})} \\
v i=\frac{(\mathrm{D} \pi) \text { Circumference of irrigated area }(\mathrm{m})}{\text { irrigation time }(\mathrm{h})} \\
v \%=\frac{v i}{v \max }
\end{array}
$$

where:

$\mathbf{v}_{\mathbf{i}}=$ Irrigation velocity, $\mathrm{m} / \mathrm{h}$.

$\mathbf{v}_{\max }=$ maximum velocity for center pivot, $\mathrm{m} / \mathrm{h}$.

$\mathbf{v}_{\%}=$ velocity percentage for center pivot,$\%$.

\section{Fertilization program:}

Amounts of fertilizers were added by traditional method according to the recommendation of Field Crop Department ,ARC, Ministry of Agricultural and Land Reclamation for maize. Field Crop Department recommended 120 unit Ammonium Nitrate 33\% N /feddan divided into three doses each of about $130 \mathrm{~kg} / \mathrm{fed}$ of Ammonium Nitrate and $100 \mathrm{~kg} /$ feddanof potassium sulphate $48 \%$.

\section{Crop measurements:}

The crop samples were taken by selecting three areas $(0.5 \mathrm{~m} \mathrm{x} 1.4 \mathrm{~m})$, the distance of area samples is 16 $\mathrm{m}$ starting at the one third center of mainline pivot and finishing at the end. Area samples contained9 plants, three samples were taken at traditional and round furrow.

Total grain yield $\left(\mathrm{Mg} / \mathrm{ha}\right.$.) and water use efficiency $\left(\mathrm{kg}\right.$ grain $\left./ \mathrm{m}^{3}\right)$ were determined after 110 days from planting when the mean moisture of kernel was $16.4 \%$

- Total grain yield, Mg./ha..

Energy analysis:

- Water use efficiency, $\mathrm{kg}$ grain $/ \mathrm{m}^{3}$ water.

Energy requirements and energy applied efficiency (EAE) were determined for MSIS according to Batty et. al.,(1975)using the following formula :

a) Power consumption use for pumping water $\left(\mathbf{B}_{\mathbf{p}}\right)$ was calculated as follows:

$$
\mathrm{Bp}=\frac{\mathrm{Q} * \mathrm{TDH} * \mathrm{Y}_{\mathrm{w}}}{\mathrm{E}_{\mathrm{i}} * \mathrm{E}_{\mathrm{p}} * 1000}
$$


Where:

Bp = Power consumption , KW,

$\mathbf{Q}=$ Total system flow rate, $\mathrm{m}^{3} / \mathrm{h}$,

TDH = Total dynamic head ,m,

$\mathbf{E}_{\mathbf{i}} \quad=$ Total system efficiency, $\%$,

$\mathbf{E}_{\mathbf{p}}=$ Pump efficiency, $\%$,

$\mathbf{Y}_{\mathbf{w}}=$ Water specific weight (taken as $9810 \mathrm{~N} / \mathrm{m}^{3}$ )

b) Pumping energy requirements $\left(\mathbf{E}_{\mathbf{r}}\right)(\mathbf{k W} . \mathbf{h})$ was calculated as follows:

$\mathbf{E}_{\mathbf{r}}=\mathbf{B}_{\mathbf{p}} * \mathbf{H}$

Where:

$\mathbf{H}=$ Irrigation time per season (h).

c) Energyappliedefficiency (EAE) was calculated as follows:

$\operatorname{EAE}(\mathrm{kg} / \mathbf{k W})=$

Total fresh yield $(\mathrm{Kg})$

Energy requirements (KW.h)

Cost analysis:

Cost analysis to evaluate the MSIS, and it was computed according to Worth and Xin (1983).

The total costs are based on 63hectares size according to market price levels of 2004 for equipment and operating irrigation process.

\section{Results And Discussion}

Modification of pivot system to be more suitable to irrigate different crops is required to redesign some parts, specially the water outlets (nozzles) to improve irrigation efficiency after modification.

\section{Determining the graduated diameters for movable surface irrigation system.:}

Changeable diameters can be calculated for many capacities for pivots with different pivot lengths according to the difference in towers number. By using last relationship (1),

\section{Evaluation uniformity of movable surface irrigation system:}

Data showed the deviation of hose discharge from the mean discharge along pivot mainline. Also average pressure head of hoses is equal to $5 \mathrm{~m}$ and it's nearly constant along pivot. It deviates ranged from 0.25 to 0.5 meter. Beside, the deference between the two lengths of hose does not affecteduniformity or pressure head along the pivot. The hoses which have $200 \mathrm{~cm}$ length are better compared withothers, because the short hose is a basic reason of water erosion beside it's not recommended to apply water for plant because of fungi diseases and chemigation.

\section{Trapezoid form (hoses length $25 \mathrm{~cm}$ and $200 \mathrm{~cm}$ ):}

Data showed that, water distribution of outlets is nearly constant for four replicates of measurements.Uniformity coefficient is high, it was $92.5 \%$ and $87.8 \%$ for hoses length $25 \mathrm{~cm}$ and $200 \mathrm{~cm}$ respectively, whichis considered excellent and good according to (Merriam and Keller, 1978) and (IRYDA, 1983).

Regarding the mean total discharge for hoses length $25 \mathrm{~cm}$, data showed that the mean total discharge of replicates of MSIS was $46.8 \mathrm{~m} 3 / \mathrm{h}$, and the mean discharge of outlets was constant $0.33 \mathrm{l} / \mathrm{s}$. On other hand, the mean total discharge of hoses length $200 \mathrm{~cm}$ was $45 \mathrm{~m}^{3} / \mathrm{h}$, and the mean discharge of outlets $0.251 / \mathrm{s}$, also the discharge stability beside the pressure head take a vibrated line as shown in Fig. (4). And the deviation of pressure head from the mean ranged between $(0.1,0.4$ meter) and $(0.2,0.5$ meter $)$ for hoses length 25 and $200 \mathrm{~cm}$ respectively (Fig.6 and 7). 


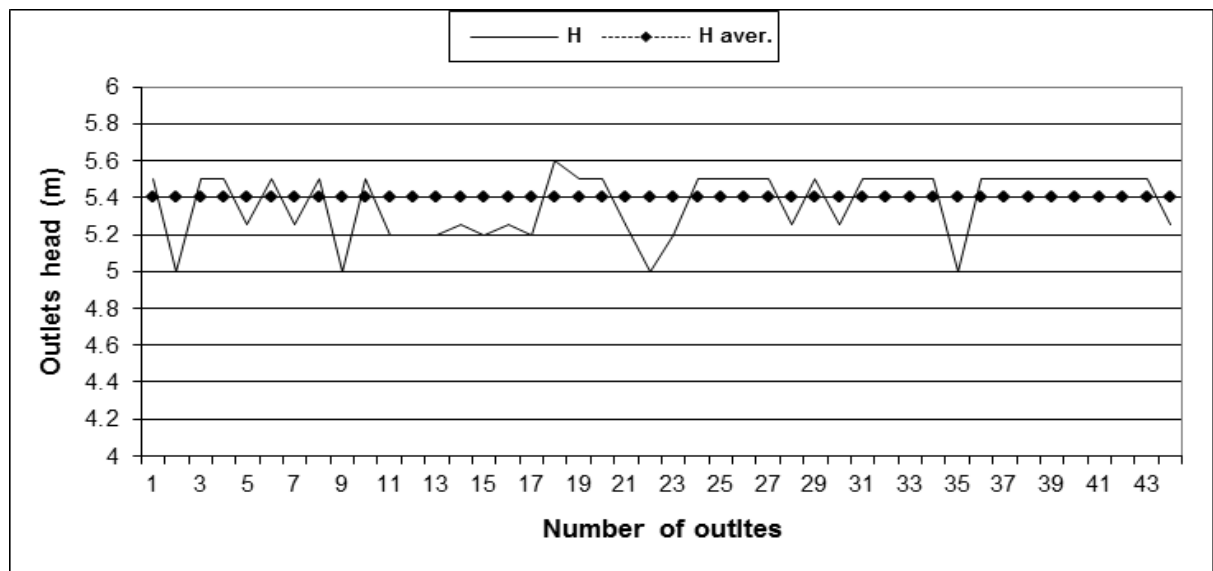

Fig. 6: Deviation of outlets piezometric head about the head piezometric at trapezoid form with short hoses.

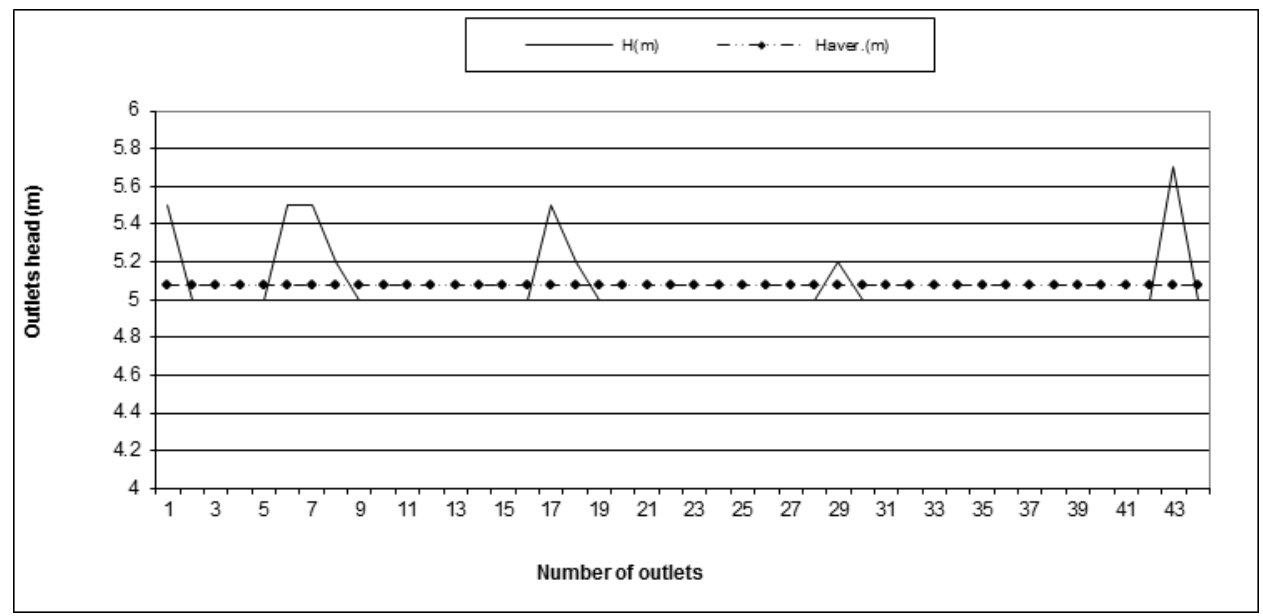

Fig.( 7): Deviation of outlets piezometric head about the meanhead piezometric at trapezoid form with long hoses.

Triangle (hoses length of $25 \mathrm{~cm}$ and $200 \mathrm{~cm}$ ) :

Data appeared that, water distribution of outlets is nearly constant for four replicates of measurements. Uniformity coefficient is high, it was $93 \%$ and $90.7 \%$ for hoses length $25 \mathrm{~cm}$ and $200 \mathrm{~cm}$ respectively, This uniformity is excellentaccording to (Merriam and Keller,1978) and goodaccording to(IRYDA,1983)for both hoses length.

Regarding the mean total discharge for different replicates for hoses length $25 \mathrm{~cm}$ data illustrated showed that, mean total discharge was $55 \mathrm{~m}^{3} / \mathrm{h}$. The mean discharge of outlets was $0.33 \mathrm{l} / \mathrm{s}$. While for hoses length of $200 \mathrm{~cm}$, the mean total discharge was $53 \mathrm{~m}^{3} /$ hand the mean discharge of outlets was $0.31 / \mathrm{s}$. The difference between mean discharge for all of simple tower (total) and mean total discharge was due to experimental errors, which result to difference of discharge measurements. The discharge stability due to the pressure head take a vibrated line as shown in Fig.( 6 and 7) and Fig.(6) showed the constant of plotting head pressure. The deviation from the mean ranged between $(0.2,0.5$ meter $)$ and $(0.2,0.8$ meter $)$ for hoses length 25 and $200 \mathrm{~cm}$ respectively. Fig.(8 and 9). 


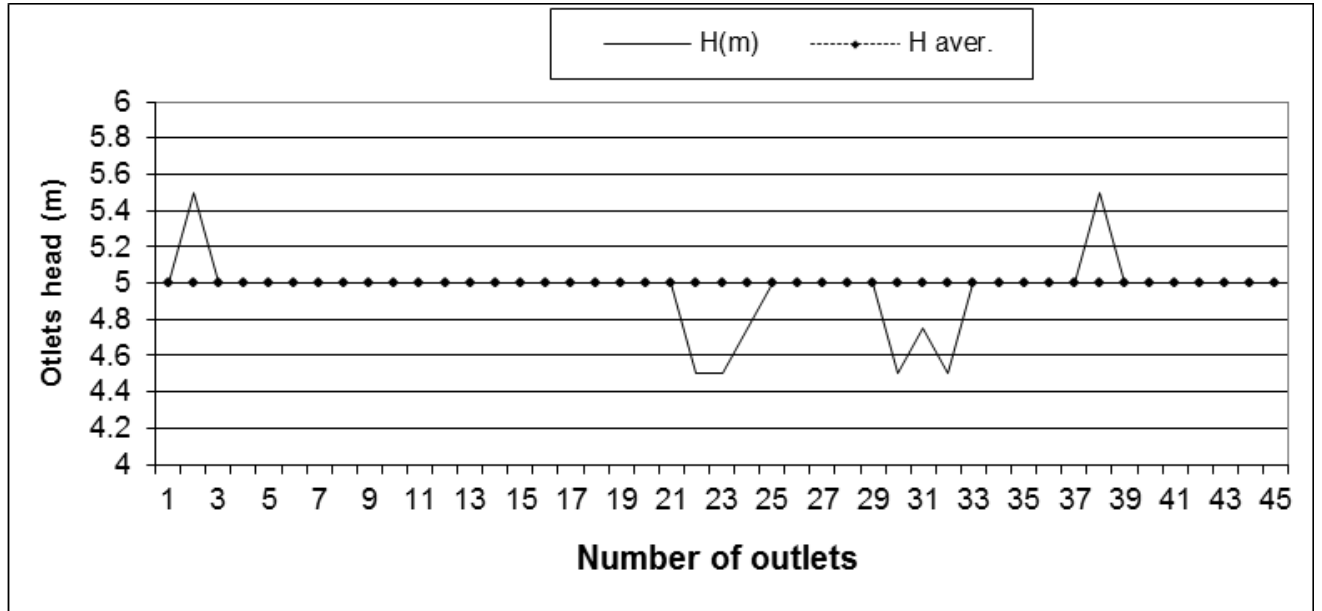

Fig. 8: Deviation of outlets piezometric head about the mean headpiezometric at triangle form with short hoses.

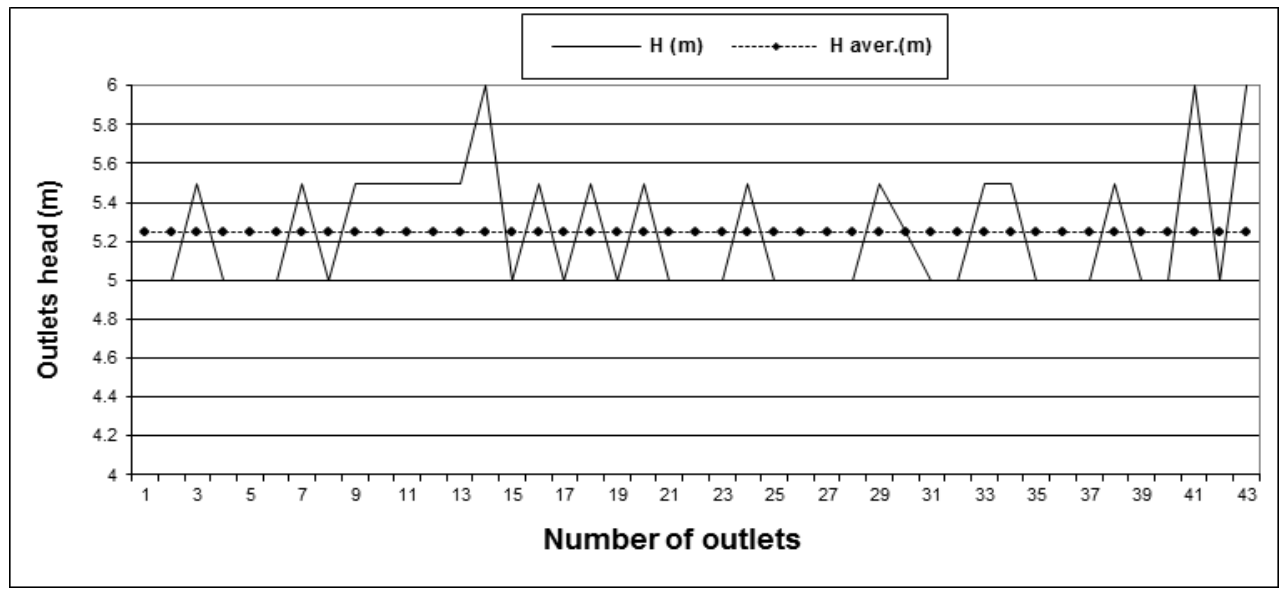

Fig. 9: Deviation of outlets piezometric head about the mean headpiezometric at triangle form with long hoses.

\section{Results of growing maize under movable surface irrigation system: \\ Water distribution:}

Water distributionunder MSIS was a very important indicator for water application efficiency and system efficiency which was $90 \%$, beside amount of applied irrigation water at season $\left(4744 \mathrm{~m}^{3} / \mathrm{ha}\right)$ while it was $\left(5702 \mathrm{~m}^{3} / \mathrm{ha}\right)$ under pivot sprinkler systems.(El-Gindy, et al 2003 ) that means applied water under MSIS lower with $16.8 \%$ of applied water under sprinkler pivot. Also, due to the ratios of water stored in the root zone to the water delivered to the field and is thus influenced by the following causes:

a - Evaporation losses from water flowing on the soil surface or in the air from sprinkler nozzle spray,

$\mathrm{b}$ - Soil surface evaporation during irrigation.

MSIS aspect involved designing a system to be used in conjunction with micro-basin land preparation or furrow diking which prevents runoff and maximizes the use of rainfall and applied irrigation water. Outlets were developed to accomplish both goals. No wind losses result since water is discharged directly into the furrow. Also, protecting plant from water which causes fungal diseases beside from pesticide hazard usage and generally chemigation when injection at MSIS.as showed at Fig.(10). 


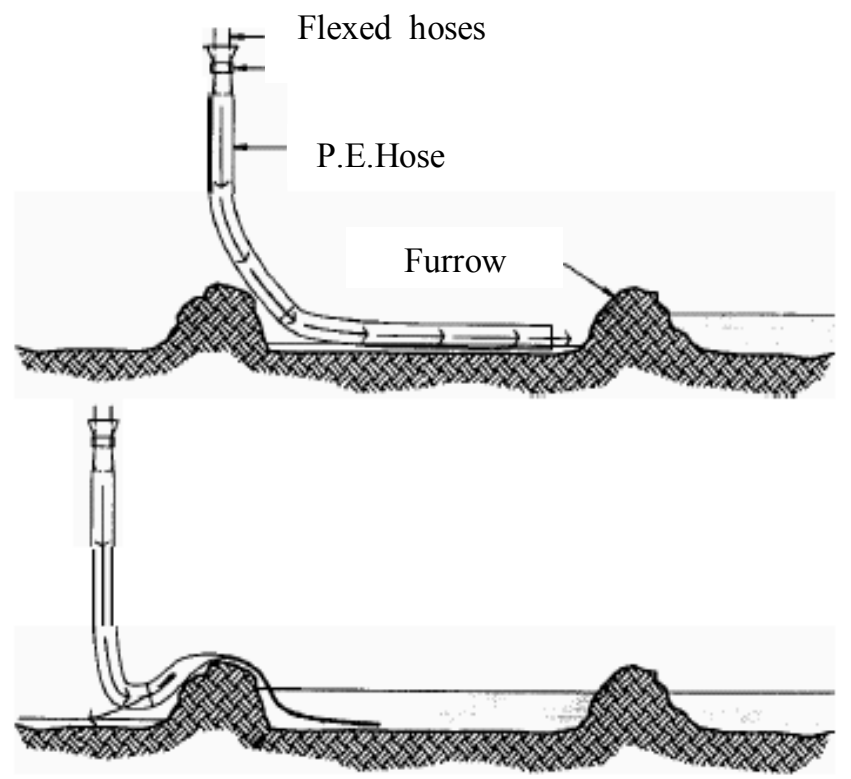

Fig. 10: MSIS outlets designed to be used in conjunctionwith furrow dikes. The hose prevents wind losses.

\section{Crop yield:}

Maize grain yield under modifiedsystem was $11.57 \mathrm{Mg}$ /ha for round furrow, while it was $12.37 \mathrm{Mg}$ /ha for traditional furrow.Difference between traditional furrow and round furrow is insignificant.It's important to mention that both maize grain yield of two furrow treatments was good according to (El-Gindy, et al. 2003 ), while maize grain yield in this study under MSIS was $11.97 \mathrm{Mg} / \mathrm{ha}$. Water use efficiency for maize was 2.5 $\mathrm{kg} / \mathrm{m}^{3}$ and $1.84 \mathrm{~kg} / \mathrm{m}^{3}$ for MSIS and sprinkler pivot respectively.

\section{Energy analysis:}

Table 2:Pump power, energy requirement, and energy appliedefficiency for both of sprinkler pivot and MSIS.

\begin{tabular}{lcc}
\hline \multicolumn{1}{c}{ Type of energy requirement } & Sprinkler pivot & MSIS \\
\hline Bp (kW) & 4 & 2.95 \\
\hline Er $(\mathbf{k W} . \mathbf{h})$ & 833 & 164 \\
\hline EAE $(\mathbf{k g} / \mathbf{k W} . \mathbf{h})$ & 10.34 & 26.4 \\
\hline
\end{tabular}

Power consumptive use for pumping water $(\mathrm{Bp})$ for sprinkler pivot was $(4 \mathrm{~kW})$, while it was $(2.96 \mathrm{~kW}$ )forMSIS. Beside, pumping energy requirement (Er) was $(833 \mathrm{~kW} . \mathrm{h})$ for irrigation season under sprinkler pivot when irrigation time during the season was (208.25 h),(El-Gindy et al. 2003). But,MSIS was (164.15 kW.h). Finally,energy applied efficiency (EAE) was $(10.34 \mathrm{Kg} / \mathrm{kW} . \mathrm{h})$ for sprinkler pivot, whileit was $(25.5 \mathrm{Kg} /$ kW.h) $(27.27 \mathrm{Kg} / \mathrm{kW} . \mathrm{h})$ for round furrow andtraditional furrow at next, it's clear that energy requirement for MSIS is lower than energy requirement at pivot, it's lower with $(26 \%-80,3 \%)$ for power consumption use for pumping water (Bp) and pumping energy requirements at next. While energy applied efficiency (EAE) of MSIS is higher than sprinkler pivot, it's higher with $(60,8 \%)$, as shown in Table (2).

\section{Cost analysis:}

By calculating both annual fixed and operating costs for MSIS, it becomes crystal clear that MSIS was more economical compared with sprinkler pivot as shown in Table (3). This difference is due to static package sprinklers compared with MSIS fittings, repairs and maintenance costs of hours per season costs beside, to the reduced of energy beside to the decrease labor costs. Data in Table(3) appears that, labor cost for MSIS was lower than sprinkler pivot by (76.6\%), cost of one $\mathrm{m} 3$ ofwater in LE for MSIS was lower than sprinkler by (20 $\%$ ), and finally, cost of unit production unit (LE/kg) for MSIS was lower than sprinkler pivot by (36 \%). 
Table 3: Cost analysis for both of MSIS and sprinklerpivot irrigation systems.

\begin{tabular}{|c|c|c|}
\hline Item & pivot & MSIS \\
\hline Pivot towers cost , LE/ha & 4285.7 & 4285.7 \\
\hline Nozzles cost ,LE/ha & 36 & 6.3 \\
\hline 1 - Capital cost , $\mathrm{LE} / \mathrm{ha}$ & 4321.7 & 4292 \\
\hline \multicolumn{3}{|c|}{2 - Annual fixed cost, LE/year } \\
\hline Deprecation & 144 & 143 \\
\hline Interest & 403 & 400 \\
\hline Taxes and Insurance & 64.8 & 64.4 \\
\hline Subtotal & 611.8 & 607.4 \\
\hline \multicolumn{3}{|c|}{3 -Annual operating costs, LE/ha } \\
\hline Labor & 300 & 70 \\
\hline Energy & 120 & 22.5 \\
\hline Repairs and maintenance & 120.65 & 42.9 \\
\hline Subtotal & 549.65 & 135.5 \\
\hline Annual Total Costs, LE/ha & 1161.5 & 742.8 \\
\hline Cost of one $\mathrm{m}^{3}$ of water $\left(\mathrm{LE} / \mathrm{m}^{3}\right)$ & 0.20 & 0.156 \\
\hline Cost of production unite (LE / kg ) & 0.1 & 0.064 \\
\hline
\end{tabular}

\section{Conclusions}

1- Felexbility of derived relationship to calculate the suitable diameters of outlets for many pivot towers. This relationship is:

$$
\mathrm{D}=536.3 \mathrm{Q}\left[0^{.5} / \mathbf{h}^{0.25}\right]
$$

2- MSIS obtained both of pivot advantages and modified surface irrigation.

3- Traingle form was the more suitable thantrapzioed form, due to facility and flexbility design. Also, micro of changbale diameters which were obtianed at trangle.

4- Category of diametres were distributed at one half of pivot mainline then the next half, because of elevation difference.

5- Uniformity coffiecent of two forms and two lengths was high .

6- Total dynamic head was reduced from (3-4 bar) at sprinkler pivot to (1.5 - 2 bar $)$ at MSIS. And consequently, at next saving energy requirment and irrigation costs.

7- The a mount of irrigation water applied by using MSIS was $16.8 \%$ less compared with sprinkler pivot systems.

8- Pulled hoses were more suitable than short hoses.

9- Chemigation was more safe with MSIS which reduce hazarad of wind evaporation, besides, preventing of green plant pollution with pestcides.

10- Water use efficiency was increasedas a result to saved wind lossesof water.

11- There's no optical difference between traditional furrow and concerting furrow because of plants density and flexibility of PE hoses.

12- Flexibility of MSIS to irrigate shrubs, small trees, and plants which are sensitive to water with any fungal disease or flowers falling.

\section{Reference}

[1]. Batty, J. C.; S. N. Hamad and J. Keller (1975).Energy inputs to irrigation. J. of Irrig. Drain. Div., ASCE, 101(IR4):293-307,USA

[2]. Barlts,S.V.;D.M,Edwards,andP.-Wu(1987).Drip Irrigation design and evaluation based on staticaluniformityconcept. In Aduncein Irrigation (ed).D.Hillel,New York Academic Press Inc.,pp67-117.

[3]. BronerI.(2002), Center pivot irrigation system ,No.4.704.,

[4]. www.ext.colostate.edu/.

[5]. Doorenobs, J.and W.O. Pruitt (1977).Guidelines for predicting crop water requirements .FAO Irrg.and Drain. paper24.Rome ,Italy: p 156.

[6]. El-Gindy, A. M.; M. F. Abd El-Salam; A. A. Abd El-Azize and E. A. El-Sahar(2003),Some engineering properties of maize plants, ears and kernels under different irrigation system.,J. Agric., Sci., Mansura Univ., 28(6):4339-4360.

[7]. FAO (1984).Guidelines for predicting crop Water requirements. FAO Irrigation and Drainage ,paper No, 24.

[8]. Helweg,O.J(1989).Evaluating the travelling trickler center pivot., ICID-Bulletin.38:1, 13-20.

[9]. IRYDA (Instituo de ReformaYdesarrolloAgrario ),1983,Normas paralaredacción de proyectos -deriegoLocalizado.Ministerio de Agricultura,Pesca Y Aimenta-ción, Madrid,Spain.

[10]. Keller ,J.andD.Karmeli(1975).Trickle irrigation design rain bird sprinkler manufacturing crop., GlendorCalfi, 91740 USA: 24 26.(cited from Rawlines,(1977).sda.gov/personnel/pdfs/Center\%20Pivot\%20Irrigation.pdf

[11]. Merriam,J.L.andJ.Keller(1978).Farm irrigation systems evaluation :Aguid for management UTAH Sates University .Logan. Utah.USA

[12]. Wilems,G.J.;D.L.Marten;R.J.Supalla,(1993),Decision support system for design of center pivots, ASAE Transaction, 37(1): 165175

[13]. Worth,B, and J.Xin(1983).Farm mechanization for profit, Granada Publishing.UK.p269. 